\title{
The Bullying Behavior in Vocational Schools and its Correlation with School Stakeholders
}

\author{
Achmad Dardiri \\ Universitas Negeri Yogyakarta, achmaddardiri@uny.ac.id \\ Farida Hanum \\ Universitas Negeri Yogyakarta,faridahanum@uny.ac.id
}

\section{Setya Raharja}

Universitas Negeri Yogyakarta, setya@uny.ac.id

\begin{abstract}
This study aims to explore: (1) the intensity of bullying, (2) the bullying process, (3) the concern of school stakeholders on bullying behaviors, and (4) the correlation between the concerns of school stakeholders and the intensity of bullying in vocational high schools in Yogyakarta. The research used a quantitative approach with ex post facto method, and was done in two vocational high schools. A total of 203 students became the samples chosen randomly based on classes. Data were collected by means of a closed-ended questionnaire in forms of a rating scale with reliability 0.845 and 0.912 , and were analyzed quantitatively using frequency, percentage, and correlation statistics. The results of the study reveal the followings. (1) Bullying often experienced by students takes the form of shoving, teasing, pinching, clawing, hitting, kicking, property damaging, hair-shirt pulling, and glaring. (2) Bullying in schools is mostly done by students individually during class and after class, and takes place in classrooms, in school yard, or in school canteens. (3) School stakeholders who are most concerned about bullying in schools are guardian teachers and guidance and counseling teachers, followed by parents-school committee members, school leaders, students, and academic staffs. (4) There is a negative correlation between the concerns of school leaders, academic staffs, parents-school committee members, and students and the intensity of bullying in schools.
\end{abstract}

Keywords: bullying in schools, concern, school stakeholder, vocational school, behavior

\section{INTRODUCTION}

One student of SMAN 3 Jakarta who was died in an extracurricular activity was allegedly considered as the victim of his senior's violence, who at that time served as a 
mentor. In this case, five senior students (four males and one female) were designated as the suspects (Kompas 4 July 2014). Bullying occurs to people across ages and gender. Victims of bullying are generally weak, shy, quiet, and special-disabled, introverted, clever, beautiful, or have certain body characteristics to be mocked (Astuti, 2008).

The phenomena found in Yogyakarta high schools show that the condition of groups, families, mass media, environment, self-esteem, seniority tradition are the factors causing bullying (Octavianto, 2017). Therefore, there is an urgent need to develop anti bullying policies in schools to identify and find ways of enabling pupils to seek out the help that they needed (Jan \& Husain, 2015). Al-Raqqad, et al. (2017) suggested that teachers and the school management have to take different measures for the purpose of reducing the bullying volume. Moreover teachers should coordinate with bully's students. Teachers and school management have to set some programs for bullies to mitigate the school bullying.

The results of Smith's (2016) study demonstrated that individual, family, class, school, and broader country factors can influence the chances of student involvement in bullying. Furthermore, Adegboyega, Okesina, \& Jacob (2017) found that there is a significant relationship between family and bullying behavior among secondary school students with disabilities in Ogbomoso South, Oyo State, Nigeria. This is reinforced by the research results by Salmi, Hariko, and Afdal (2018) which confirms that good selfcontrol can prevent bullying.

Based on the aforementioned studies, bullying in schools cannot be separated from the school's situation and condition, school's components, and its environment. This research is prepared as a basis for the educational development that can overcome bullying in schools. Therefore, this study examines the bullying and its relationship with the school's component, especially their concern about bullying among the students.

Vocational Schools in Indonesia include engineering Vocational Schools which were previously known as Sekolah Teknik Menengah (STM) and non-engineering Vocational High School which were previously named Sekolah Menengah Ekonomi Atas (SMEA). Engineering vocational high school students are identical with brawling students. Most of the perpetrators of various brawls riffing in the capital city are engineering vocational school students. It is believed that male sex domination gives the social conditions (social climate) of the engineering vocational high schools seems a harsh impression. In addition, the highly heterogeneous background of students in engineering vocational schools can lead to occasional interaction frictions among students. In such conditions weak and less confident students are vulnerable to bullying behavior in schools.

The recent rise of bullying in schools, even one resulting in the student's death, has signaled that there are something amiss with the interaction process amongst the school community members, which later has an impact on students' misbehaviors on some students. Besides educational factors, the boundless rapid flow of information through various media is also often accused of being the cause of value shift in society. Negative effects due to technology developments are reflected in the increasingly complex social phenomena of children and adolescents among which are (1) the decline of good 
manners and politeness of students to teachers and to parents, (2) bullying behaviors that are increasingly getting worse in school, (3) continuous brawls and criminals committed by students, and (4) sexual harassment behaviors that occurs in schools. All of these are social phenomena resulted from the school's failure in producing active and moral students.

In efforts to prevent bullying in schools, all school stakeholders and all teachers should be involved. A comprehensive program involving all elements will be more effective at preventing bullying and improving school safety than focusing on some students through an individual approach (Hidayati, 2012).

Education should provide wide opportunities for the development of virtues by not only producing mathematicians, biologists, economists, experts of social sciences, etc., but also producing those who can act ethically and with integrity. Thus, mental, moral, and spiritual decline of the nation can be inhibited through education so that later on, people can intelligently determine and choose which things are beneficial or harmful for their life.

Furthermore, humanistic education can bring back the people to their good potentials. To achieve this, a pedagogical commitment in building future fundamental characters that are full of by human values should be built. In order to realize humanistic education that can provide comfort to learning and interaction in schools, wise strategies and methods are needed in building school environment, so that bullying behaviors can be minimized or possibly eliminated. In order for that hope to realize, the school needs some assistance from universities, in this case the considerations or suggestions from educational experts to overcome these problems. One of the efforts should be done is conducting a research study that can suggest an appropriate model for education to be implemented immediately. With the framework of the problems and objectives, a study using research and development (R\&D) procedures to develop an education model to overcome bullying in schools was important to be done (Ulfah, S.R., 2015).

Based on the background of the problems explained above, this research was focused on bullying problem that occurred in engineering vocational high schools which was previously known as Sekolah Teknik Menengah (STM) in Yogyakarta. The study aims to identify and describe: (1) the intensity of bullying in school, (2) the bullying process in schools, (3) the concerns of school stakeholders about bullying behavior in schools, and (4) the correlation between the concerns of school stakeholders and the intensity of bullying in schools.

This research is an initial step as a needs assessment stage to produce an education model that can be used in overcoming bullying behavior in schools, helping teachers and schools to design, direct, and conduct education that overcomes bullying behaviors in schools so that schools can be safe and comfortable for all of their stakeholders. In particular, this research would develop a module for an education implementation model to cope with bullying in engineering vocational high school (STM) in Yogyakarta. This module was expected to be used by all parties related to the implementation of education in schools. 


\section{LITERATURE REVIEW}

Bullying is a form of aggression (Thompson, Arora, and Sharp, 2002). Bullying is typically a part of repeated acts of aggression by stronger children against weaker ones mentally and physically. Bullying is identified as an unacceptable behavior, however if it is failed to handle, bullying can be a more severe act of aggression. Ken Riigby (Elliot, 2002) says that bullying is a desire to harm another person. This desire is preserved into action, causing a person to suffer. This action is performed directly by a stronger, irresponsible person or group repetitively and satisfyingly.

Besides, bullying includes the act of intimidating and forcing a weaker individual or group to do something out of their will, with the intention of physically, mentally or emotionally harmful through harassment and assault. The most common forms of bullying especially in schools are verbal abuse which usually comes in the form of mockery, teasing, or derision, for example in mentioning the victim's name, physical condition, and weakness. If such behavior is not noticed early, this form of abuse can lead to physical terror, such as kicking, thrashing, hitting, and even rape (the Asian Parent Indonesia, 2010).

Bullying can also be considered as a form of child abuse committed by peers to someone who is "inferior" or weaker to gain a certain advantage or satisfaction. Bullying usually occurs repeatedly, and even systematically. According to the World Health Organization, bullying is all forms of bad treatment, whether physical, emotional, and/or sexual one, neglectful or negligent treatment, or child exploitation (Asikin, 2009).

Bullying in Yogyakarta high schools can be in forms of physical, verbal, and cyber bullying (Octavianto, 2017). Physical bullying includes a cynical glance, slapping, hitting; verbal bullying includes expressing rude and intimidating words, taunting, spreading gossip; cyber bullying constitutes threatening someone through social media. Furthermore, Antiri (2016) who conducted his study in Ghana senior high schools stated that the various types of bullying occuring in schools comprise physical, social, verbal, cyber, and psychological bullying.

Bullying is influenced by social values of the society. In an aggressive society full of dynamical conflicts such as modern society, serious bullying cases often occur resulting in hurt, injury, and even death. Bullying actors are usually children who have greater authority and bravery, such as seniors, students with bigger posture, or aggressive children who bully seemingly week and fearful children. Thus, bullying is a type of violence.

Astuti (2008) suggests that bullying cases in schools may be caused by the following situations and conditions: (1) characteristics of descriptive behavior among teachers and students, (2) lack of supervision and ethical guidance from teachers and security guards, 3) a large gap between rich and poor students, (4) very rigid or too weak discipline, and (5) improper guidance and inconsistent rules. 
Violence is a behavior deviating the code of ethics and rules in education, both in the physical form and in the harassment of one's rights. The perpetrators may be school leaders, teachers, students, academic staffs, parents, or guardians, even the society. Done by breaking the authority of the institution, the code of ethics of teachers, and school rules, then violence can lead to human right contraventions, and even criminal acts. During this time, value education in schools is just conducted in the form of knowledge delivery (cognitive domain). Human values such as justice, democracy, freedom, social solidarity, equality of rights, and law, etc. are not sufficiently taught, but must be implemented through students' attitude and behavior (affective and psychomotoric domains). In brief, value education can be done by means of internalization of values and awareness raising through early education humanization (Assegaf, 2003).

In some cases, most of bullying victims in schools are quiet students who do not complain for fear of receiving bullying reactions so that bullying behavior is often detached from the observations of teachers and other students, including the victim's parents. However, these victims usually show symptoms such as: sleeping difficulty, difficulty paying attention in class or in any activity, often making excuses for skipping school activities, and suddenly distancing themselves from previously favored activities (the Asian Parent Indonesia, 2010).

To prevent students from bullying in schools, there are several ways that can be done by students such as seeking school assistance and making friends with other people outside school. Meanwhile, talking to bullies, empowering children who are vulnerable to bullying, children monitoring, and telling the children about life experiences are efforts that can be done by both parents and teachers (Michael, H., 2017).

To eliminate or minimize bullying in schools, moral education is very important to be instilled and implemented in the student behaviors in school. The earlier the students receive moral education the easier they become moral people. Moral is very important in underlying student behaviors when interacting with others because moral values contain ethical and human values. When people have good morals, they surely will not engage in bullying or other disgraceful behaviors. Therefore, to prevent students being bullies, moral education should be given from the very beginning (Amaniya, 2019).

Furthermore, education should be able to help students in learning to shape themselves into good and moral human beings who can distinguish good and bad behaviors, and dare to decide to act properly. These things are often not directly learned in schools; nevertheless every individual in schools should have ample experiences in moral training and carrying out moral learning.

Komensky (Koesoema A., D, 2007) considers that the products of education cannot be obviously seen. The work of teachers is considered as a rough form, not yet a real work. It means that a teacher, as an educator who teaches wisdom, should enable and support every individual to build their good moral. This is called moral education, a process of education that actually makes people the most special creatures. While according to Socrates, a man is judged based on his soul; not his ability to speak in public. Soul is something that distinguishes one man from another. It is in this soul that people do 
thinking, acting, and affirming the moral values in his life.

The famous Socrates paradigm is "know thyself". Recognizing yourself (who am I) means "nurturing our soul". Knowing ourselves does not merely mean that we know our own names, but more than that, we investigate the dimensions of our interiority as human beings. Human nature is in their soul. Through their interiority people seek to realize themselves through spiritual values. These values emerge from true knowledge so that people can carry out those values in life. Without true knowledge of moral values, it is not possible to do moral actions, for moral actions are conscious and free actions done for the sake of value within oneself. This is what really brings an individual to what Socrates calls happiness.

Komensky argues that an approach for the formation of the souls of the students in the school, a righteous morality and devotion so that each individual actually lives in his moral values as an integral part of his personality traits. Komensky (Koesoema A., D, 2007) gives 11 canons for a moral lesson in school, as follows: (1) the instillation of all values of virtues to the younger generation, (2) the ability to manage intellectual considerations in distinguishing clearly what is good and what is bad (prudenza), (3) justice, the true virtue which lies in the ability of oneself to consider and judge things in a balanced and equitable way or in rewarding them objectively for what they are, (4) ability to actualize and satisfy one's desires and instincts in a balanced and appropriate way. (5) persistence, performing self-control, enduring in difficulties and sufferings, being happy and optimistic anytime, and being able to withstand impatience, complain or anger. (6) fair which means being able to do things in a way that is not evil or destructive to others, giving others' rights. (7) sincerity on what is being faced and willing to bear the consequences, suffering, tiredness of the task being done. (8) a loyal ability in doing the tasks entrusted to him. (9) being able to value hard work so that students are willing to do things in earnest and pleasant ways. (10) readiness and generosity in serving others. (11) the instillation of these values and virtues from the early childhood.

The eleven moral teaching canons suggested by Komensky serve as pedagogy for every individual, especially for education related parties. Their opinions will be important to be referred and noticed in the development of educational model to cope with bullying.

\section{METHOD}

This research uses quantitative approach with survey design. This study was conducted to make a generalization of limited observation into a generally accepted balance for the population (Lembaga Penelitian, 2010): This research was conducted in 2015 in two vocational high schools or Sekolah Menengah Kejuruan (SMK) in Yogyakarta, namely SMKN 2 Yogyakarta and SMK PIRI 1 Yogyakarta, with the population of this study are grade $\mathrm{X}$ and XI students from the two schools, as many as 1760 students. The detail numbers of the students are 635 for Grade X and 620 for Grade XI of SMKN 2 Yogyakarta, while students of SMK PIRI 1 Yogyakarta are 247 and 258 for grade X and XI respectively. Furthermore samples were taken using stratified random sampling technique based on the grade with a total of 203 students. They were 95 students from 
Grade X and 108 students from Grade XI. The research variables include dependent and independent variables. The dependent variable in this study is the intensity of bullying in schools includes 4 sub variables, namely the intensity of physical, non-physical verbal, non-physical non-verbal direct, and non-physical non-verbal indirect bullying. The independent variable of this study is the concern of the school stakeholders that includes 5 sub variables, namely the concern of students, teachers, school leaders, academic staffs, and parents-school committees. Data were collected by means of a closed questionnaire with its rating scale given to the students. The instrument's validity was examined using content validity, while its reliability was tested using the Cronbach Alpha technique. The reliability coefficient of the bullying intensity instrument was 0.854 and the school component's concern instrument was 0.912 . The analysis was done quantitatively using frequency, percentage, and correlation statistical analyses with product moment or Person Correlation technique.

\section{FINDINGS}

The research findings are presented in an organized way based on the problems proposed.

\section{Intensity of Bullying at School}

Based on the confession and the experience of the students, there are 22 bullying behaviors that occur in schools. These 22 behaviors are grouped into 4 categories namely physical, non-physical verbal, non-physical non-verbal direct, and non-physical non-verbal indirect bullying.

The physical type of bullying includes 10 behaviors. Physical bullying that occurs in schools and is experienced by more than $30 \%$ of students comprises 6 behaviors such as shoving, pinching, clawing, kicking, property damaging, and hair-shirt pulling, while 4 other behaviors (locking someone somewhere, biting, punching, and twisting) are experienced by $14-20 \%$ of the students. The following table illustrates the physical bullying behaviors that occur in schools.

Table 1

Physical Bullying Behaviors Occurring in Schools

\begin{tabular}{clccccccc}
\hline No & Bullying Behavior & $\mathrm{N}$ & \multicolumn{2}{c}{ Often } & \multicolumn{3}{c}{ Sometimes } & \multicolumn{2}{c}{ Never } \\
\cline { 5 - 9 } & & & $\mathrm{f}$ & $(\%)$ & $\mathrm{f}$ & $(\%)$ & $\mathrm{f}$ & $(\%)$ \\
\hline 1 & shoving & 202 & 21 & 10.4 & 97 & 48.0 & 84 & 41.6 \\
2 & pinching, clawing & 202 & 8 & 4.0 & 88 & 43.6 & 106 & 52.4 \\
3 & hitting & 202 & 6 & 3.0 & 85 & 42.0 & 111 & 55.0 \\
4 & kicking & 202 & 6 & 3.0 & 85 & 42.0 & 111 & 55.0 \\
5 & property damaging & 201 & 9 & 4.5 & 72 & 35.8 & 120 & 59.7 \\
6 hair-shirt pulling & 202 & 11 & 5.4 & 67 & 33.2 & 124 & 61.4 \\
7 & locking someone somewhere & 200 & 2 & 1.0 & 38 & 19.0 & 160 & 80.0 \\
8 & biting & 202 & 6 & 3.0 & 34 & 16.8 & 162 & 80.2 \\
9 & punching & 200 & 2 & 1.0 & 30 & 15.0 & 168 & 84.0 \\
10 & twisting & 201 & 2 & 1.0 & 27 & 13.4 & 172 & 85.6 \\
\hline & Average & & 7 & 3.6 & 62 & 30.9 & 132 & 65.5 \\
\hline
\end{tabular}

The second type of bullying is non-physical verbal bullying. This sort of bullying 
includes 5 behaviors, but there are two prominent ones, namely teasing and investigating. More than $50 \%$ students were admitted being teased or insulted by their friends. Meanwhile, the victims of threatening, intimidating, and extorting consist of $11 \%-19 \%$ of the total students. The occurrences of non-physical verbal bullying behaviors are described in detail in the following table.

Table 2

Non-Physical Verbal Bullying Occurring in Schools

\begin{tabular}{|c|c|c|c|c|c|c|c|c|}
\hline \multirow{2}{*}{ No } & \multirow{2}{*}{$\begin{array}{l}\text { Bullying } \\
\text { Behavior }\end{array}$} & \multirow{2}{*}{$\mathrm{N}$} & \multicolumn{2}{|c|}{ Often } & \multicolumn{2}{|c|}{ Sometimes } & \multicolumn{2}{|c|}{ Never } \\
\hline & & & $\mathrm{f}$ & $(\%)$ & $f$ & $(\%)$ & f & $(\%)$ \\
\hline 1. & teasing & 202 & 24 & 11.9 & 93 & 46.0 & 85 & 42.1 \\
\hline 2. & instigating & 201 & 4 & 2.0 & 54 & 26.9 & 143 & 71.1 \\
\hline 3. & threatening & 201 & 4 & 2.0 & 36 & 17.9 & 161 & 80.1 \\
\hline 4. & intimidating & 199 & 1 & 0.5 & 27 & 13.6 & 171 & 85.9 \\
\hline 5. & extorting & 201 & 4 & 2.0 & 19 & 9.5 & 178 & 88.5 \\
\hline & Means & & 7 & 3.7 & 46 & 22.8 & 148 & 73.5 \\
\hline
\end{tabular}

The next type of bullying is non-physical non-verbal direct bullying. This form of bullying includes 3 behaviors. They are cheating, discriminating, and alienating. The victims of cheating behavior reached almost half of the students $(43.7 \%)$, while other those of two other behaviors were fewer than $30 \%$ of students. The following table presents the non-physical non-verbal direct bullying behavior data based on what directly experienced by the students.

Table 3

Non-Physical and Non-Verbal Direct Bullying Occurring in Schools

\begin{tabular}{|c|c|c|c|c|c|c|c|c|}
\hline \multirow[t]{2}{*}{ No } & \multirow{2}{*}{ Bullying Behavior } & \multirow{2}{*}{$\mathrm{N}$} & \multicolumn{2}{|c|}{ Often } & \multicolumn{2}{|c|}{ Sometimes } & \multicolumn{2}{|c|}{ Never } \\
\hline & & & $\mathrm{f}$ & $(\%)$ & $f$ & $(\%)$ & $\mathrm{f}$ & $(\%)$ \\
\hline 1 & cheating & 199 & 7 & 3.5 & 80 & 40.2 & 112 & 56.3 \\
\hline 2 & discriminating & 200 & 6 & 3.0 & 46 & 23.0 & 148 & 74.0 \\
\hline 3 & alienating & 201 & 2 & 1.0 & 28 & 13.9 & 171 & 85.1 \\
\hline & Means & & 5 & 2.5 & 51 & 25.7 & 144 & 71.8 \\
\hline
\end{tabular}

The fourth type of bullying is non-physical non-verbal indirect bullying which also includes 3 behaviors. The student's most experienced bullying behavior is glaring $(30 \%$ of students), while two other behaviors, scaring and rebuking were experienced by less than $30 \%$ of students. In detail, non-physical non-verbal indirect bullying behaviors are presented in the following table.

Table 4

Non-Physical and Non-Verbal Indirect Bullying Occurring in Schools

\begin{tabular}{|c|c|c|c|c|c|c|c|c|}
\hline \multirow{2}{*}{ No } & \multirow{2}{*}{$\begin{array}{l}\text { Bullying } \\
\text { Behavior }\end{array}$} & \multirow{2}{*}{$\mathrm{N}$} & \multicolumn{2}{|c|}{ Often } & \multicolumn{2}{|c|}{ Sometimes } & \multicolumn{2}{|l|}{ Never } \\
\hline & & & $f$ & $(\%)$ & $f$ & $(\%)$ & $\mathrm{f}$ & $(\%)$ \\
\hline 1. & glaring & 197 & 8 & 4.1 & 51 & 25.9 & 138 & 70.0 \\
\hline 2. & scaring & 197 & 6 & 3.0 & 49 & 24.9 & 142 & 72.1 \\
\hline 3. & rebuking & 196 & 6 & 3.1 & 39 & 19.9 & 151 & 77.0 \\
\hline & Means & & 7 & 3.4 & 46 & 23.6 & 144 & 73.0 \\
\hline
\end{tabular}

The whole bullying behaviors above are types of bad behaviors both physical and nonphysical ones. This is in accordance with the statement of World Health Organization, 
that stated that bullying is all sorts of ill-treatment, whether physical, emotional and/or sexual, neglectful or negligent treatment, or exploitation of children.

Of the above four types of bullying, the largest percentage of bullying behaviors occurred to students in school are: shoving, teasing, pinching, clawing, hitting, kicking, cheating, property damaging, hair-shirt pulling, and glaring. This means that those all ten bullying behaviors should be the concern for all school stakeholders in order to be avoided by the students at school. Further observation shows that there is no different types of bullying between female and male students. In other words, both female and male students tend to experience bullying in school.

\section{Bullying Process in School}

The bullying process in schools in this study was observed from its perpetrator, time, and place of bullying, considering whether the bullying is performed individually or collectively or unorganized individuals or groups. Time of bullying means that the behaviors may occur at any time, either during the class or after the class, before class, or during school breaks. Quantitatively, bullying process in schools is displayed in Table 5 .

Table 5

Bullying Process in Schools

\begin{tabular}{|c|c|c|c|c|c|c|}
\hline \multirow{2}{*}{ No. } & \multirow{2}{*}{ Process } & \multirow{2}{*}{$\mathrm{N}$} & \multicolumn{2}{|c|}{ Yes } & \multicolumn{2}{|c|}{ No } \\
\hline & & & $\mathrm{f}$ & $(\%)$ & $f$ & $(\%)$ \\
\hline \multirow[t]{4}{*}{1.} & Perpetrator: & & & & & \\
\hline & a. individual & 180 & 96 & 53.3 & 84 & 46.7 \\
\hline & b. organized group & 183 & 90 & 49.2 & 93 & 50.8 \\
\hline & c. unorganized group & 179 & 86 & 48.0 & 93 & 52.0 \\
\hline \multirow[t]{6}{*}{2.} & Time: & & & & & \\
\hline & a. during class & 181 & 96 & 53.0 & 85 & 47.0 \\
\hline & b. after class & 185 & 97 & 52.4 & 88 & 47.6 \\
\hline & c. after school & 179 & 86 & 48.0 & 93 & 52.0 \\
\hline & d. before class & 181 & 85 & 47.0 & 96 & 53.0 \\
\hline & e. during the school break & 183 & 84 & 45.9 & 99 & 54.1 \\
\hline \multirow[t]{6}{*}{3.} & Place: & & & & & \\
\hline & a. school canteen & 180 & 91 & 50.6 & 89 & 49.4 \\
\hline & b. school yard & 181 & 91 & 50.3 & 90 & 49.7 \\
\hline & c. in the classroom & 185 & 93 & 50.3 & 92 & 49.7 \\
\hline & d. outside the classroom & 187 & 92 & 49.2 & 95 & 50.8 \\
\hline & e. school garden & 179 & 85 & 47.5 & 94 & 52.5 \\
\hline
\end{tabular}

Based on the above table, it can be seen that almost half $(50 \%)$ of students stated that the bullying in schools was done individually or by organized unorganized groups, taken place during class as well as after class, after school, before class, in school canteen, school yard, in the classroom, outside the classroom, as well as in the school garden.

The table above also shows that bullying in schools is mostly done by students individually, done during class and after class, with locations in the classroom, in the school yard, or in the school canteen. Ken Riigby (Elliot, 2002) asserts that bullying 
represents a desire to harm, which goes into action, and causes a person to suffer. This action is performed directly by a stronger, irresponsible person or group repetitively and satisfyingly.

\section{The Concern of School Stakeholders about Bullying in Schools}

The school stakeholders referred to in this study are students, teachers, school leaders, academic staffs, and parents and school committees. Quantitatively, the concern of school stakeholders about the occurrence of bullying in schools can be observed in the following table.

Table 6

The School Stakeholders' Concern for Bullying Occurring in Schools

\begin{tabular}{lllcccccc}
\hline \multirow{2}{*}{ No. } & \multirow{2}{*}{ School Stakeholder } & \multirow{2}{*}{$\mathrm{N}$} & \multicolumn{2}{c}{ Concerned } & \multicolumn{2}{c}{ Less Concerned } & \multicolumn{2}{c}{ No Concern } \\
\cline { 4 - 8 } & & & $\mathrm{f}$ & $(\%)$ & $\mathrm{f}$ & $(\%)$ & $\mathrm{f}$ & $(\%)$ \\
\hline 1 & teachers & 200 & 81 & 40.7 & 55 & 27.7 & 63 & 31.5 \\
2 & parents-school & 198 & 73 & 36.8 & 67 & 33.7 & 58 & 29.5 \\
& committee & & & & & & & \\
3 & school leaders & 200 & 69 & 34.5 & 59 & 29.5 & 72 & 34.0 \\
4 & students & 199 & 60 & 29.9 & 84 & 42.0 & 56 & 28.1 \\
5 & academic staffs & 197 & 57 & 28.9 & 97 & 49.2 & 43 & 25.9 \\
\hline & Total/Means & & 68 & 34.2 & 72 & 36.4 & 58 & 29.8 \\
\hline
\end{tabular}

The table above shows that among school stakeholders, the most concerned ones are teachers ( $40.7 \%$ of students expressed that teachers concerned). Besides, parents-school committees and school leaders also show considerable concerns for the occurrence of bullying in schools $(36.8 \% ; 34.5 \%$ of students stated that both groups concerned). Meanwhile, the concern of students and academic staffs was only felt by less than $30 \%$ of students $(29.9 \%, 28.9 \%)$. In overall, the three largest sequences of concerns for bullying in schools, are guardian teachers, guidance and counseling teachers, and parents of bullying victims.

Further analysis of the concern of each school stakeholder shows the following conditions. (1) The most concerned teachers are the guardian teachers, followed by guidance and counseling teachers, and subject teachers. (2) The most concerned parents/committees are the parents of the bullying victims, committee members, and the parents of bullies. (3) The school principals were more concerned than the vice principals. (4) The most concerned students are the victims, followed by OSIS (student union) members, and the bullies. (5) The school keepers or the canteen staffs were more concerned than academic staffs.

In general, the concern given by all school stakeholders will be able to prevent, reduce, or even stop bullying that occurs in schools. Hidayati (2012) states that in efforts to prevent bullying, all school stakeholders including all teachers should be involved. A comprehensive program involving all school elements will be more effective at preventing bullying and improving school security than focusing on some students through an individual approach. In other words, the concern of all the school stakeholders would be an important issue in dealing with bullying in schools.

The Correlation between School Stakeholder Concerns and the Intensity of 


\section{Bullying Occurrence}

Bullying phenomena in schools may be caused by school situation and condition, i.e. lack of supervision and ethical guidance from teachers and security guards, and inappropriate guidance and inconsistent regulations (Astuti, 2008). To prevent bullying, a full involvement of school stakeholders is required. One of the involvement forms is in the school stakeholder concerns for the occurrence of bullying in schools, which in turn will prevent or reduce the occurrence of bullying. The following analysis results present the correlation between school stakeholder concerns and the intensity of bullying occurrence in schools.

Table 7

The Correlation between School Stakeholder Concerns and the Intensity of Bullying Occurrence in Schools

\begin{tabular}{|c|c|c|c|c|c|c|}
\hline Variable & & $\begin{array}{l}\text { The } \\
\text { Intensity of } \\
\text { Physical } \\
\text { Bullying }\end{array}$ & $\begin{array}{l}\text { The } \\
\text { Intensity of } \\
\text { Non- } \\
\text { physical } \\
\text { Verbal } \\
\text { Bullying }\end{array}$ & $\begin{array}{l}\text { The Intensity of } \\
\text { Non-physical } \\
\text { Non-verbal } \\
\text { Direct Bullying }\end{array}$ & $\begin{array}{l}\text { The Intensity } \\
\text { of Non- } \\
\text { physical Non- } \\
\text { verbal Indirect } \\
\text { Bullying }\end{array}$ & $\begin{array}{l}\text { The } \\
\text { Intensity of } \\
\text { Bullying in } \\
\text { Schools }\end{array}$ \\
\hline \multirow[t]{3}{*}{ Student Concern } & Pearson Correl. & .023 & -.017 & -.022 & -.021 & .001 \\
\hline & Sig. (2-tailed) & .762 & .824 & .766 & .781 & .994 \\
\hline & $\mathrm{N}$ & 179 & 179 & 179 & 179 & 179 \\
\hline \multirow[t]{3}{*}{ Teacher Concern } & Pearson Correl. & .068 & .034 & .007 & .045 & .056 \\
\hline & Sig. (2-tailed) & .368 & .649 & .921 & .550 & .460 \\
\hline & $\mathrm{N}$ & 179 & 179 & 179 & 179 & 179 \\
\hline School Leader & Pearson Correl. & -.051 & -.110 & -.118 & -.112 & -.097 \\
\hline \multirow[t]{2}{*}{ Concern } & Sig. (2-tailed) & .498 & .145 & .116 & .134 & .196 \\
\hline & $\mathrm{N}$ & 179 & 179 & 179 & 179 & 179 \\
\hline Academic Staff & Pearson Correl. & -.081 & -.056 & -.125 & -.070 & -.094 \\
\hline \multirow[t]{2}{*}{ Concern } & Sig. (2-tailed) & .282 & .458 & .095 & .351 & .212 \\
\hline & $\mathrm{N}$ & 179 & 179 & 179 & 179 & 179 \\
\hline Parent and & Pearson Correl. & .002 & .002 & -.082 & -.031 & -.019 \\
\hline Committee & Sig. (2-tailed) & .978 & .974 & .273 & .678 & .805 \\
\hline Concern & $\mathrm{N}$ & 179 & 179 & 179 & 179 & 179 \\
\hline
\end{tabular}

Based on Table 07, there are two patterns of correlation between school stakeholder concerns and the intensity of bullying occurrence in schools, whether viewed from each type of bullying or from the overall bullying behaviors. The first pattern shows no correlation between the two variables (with the very small or even zero $r$ coefficient), while the second pattern shows a negative correlation (with negative $r$ coefficient). The following discussions describe the detailed results of the analysis.

a. The correlation between school stakeholder concerns and the intensity of physical bullying in schools

1) There is no correlation between student and teacher concerns and the intensity of physical bullying in schools

2) There is a negative correlation between the concern of school leaders, academic staffs, and parents-school committees and the intensity of physical bullying in schools 
These conditions indicate that the more concerned the school leaders, academic staffs, and parents-school committees the lower the intensity of physical bullying in schools. Conversely, if less concern from school leaders, academic staffs and parents-school committees, the intensity of physical bullying in schools will increase. Meanwhile, the concern of students and teachers has no correlation with the intensity of bullying in schools.

b. The correlation between school stakeholder concerns and the intensity of nonphysical verbal bullying in schools

1) There is no correlation between the concerns of teachers and parents-school committee members and the intensity of non-physical verbal bullying in schools.

2) There is a negative correlation between the concerns of students, school leaders, and academic staffs and the intensity of non-physical verbal bullying in schools.

The results of the correlation analysis indicate that the concerns of students, school leaders, and academic staffs tend to reduce the intensity of non-physical verbal bullying in schools. However, teacher and parent-school committee concerns have a very little correlation with the intensity of non-physical verbal bullying in schools.

c. The correlation between school stakeholder concerns and the intensity of nonphysical non-verbal direct bullying in schools

3) There is no correlation between the concerns of teachers and the intensity of nonphysical non-verbal direct bullying in schools.

4) There is a negative correlation between the concerns of students, school leaders, academic staffs, and parents-school committee members and the intensity of non-physical non-verbal direct bullying in schools.

The results of the correlation analysis reveal that the concerns of teachers have nothing to do with the intensity of non-physical non-verbal direct bullying in schools, and the concerns of students, school leaders, academic staffs, and parents-school committee members tend to decrease the intensity of non-physical non-verbal direct bullying in schools. The more concerns the students, school leaders, academic staffs, and parentsschool committees give, the lower the intensity of non-physical non-verbal direct bullying in schools is.

d. The correlation between school stakeholder concerns and the intensity of nonphysical non-verbal indirect bullying in schools

1) There is no correlation between the concerns of teachers and the intensity of nonphysical non-verbal indirect bullying in schools.

2) There is a negative correlation between the concerns of students, school leaders, academic staffs, and parents-school committee members and the intensity of non-physical non-verbal indirect bullying in schools. 
In line with the occurrence of non-physical non-verbal indirect bullying, the teacher concerns have no correlation with the intensity of non-physical non-verbal indirect bullying in schools. Moreover, the concern of students, school leaders, academic staffs, and parents-school committees tend to be able to lower the intensity of non-physical non-verbal indirect bullying in schools.

e. The correlation between school stakeholder concerns and the intensity of bullying in schools

1) There is no correlation between teacher and student concerns and the intensity of bullying in schools.

2) There is a negative correlation between the concerns of school leaders, academic staffs, and parents-school committees and the intensity of bullying in schools.

Of the overall bullying behaviors that occur in schools, the concerns of school leaders, academic staffs, and parents-school committees decrease the intensity of bullying behaviors in schools, while the concern of teachers and students is not closely correlated with the occurrence of bullying behaviors in schools.

Table 8

The Tendency of Negative Correlations between School Stakeholder Concerns and the Decreasing Occurence of Bullying

\begin{tabular}{|c|c|c|}
\hline No. & $\begin{array}{l}\text { Concerned } \\
\text { School Stakeholders }\end{array}$ & $\begin{array}{l}\text { Types of Bullying with } \\
\text { Decereasing Occurence }\end{array}$ \\
\hline 1. & $\begin{array}{l}\text { - } \text { school leaders } \\
\text { - academic staffs } \\
\text { - parents-school committee members }\end{array}$ & physical bullying \\
\hline 2. & $\begin{array}{l}\text { - } \text { students } \\
\text { - school leaders } \\
\text { - academic staffs }\end{array}$ & non-physical verbal bullying \\
\hline 3. & $\begin{array}{l}\text { - } \text { students } \\
\text { - } \text { school leaders } \\
\text { - } \text { academic staffs } \\
\text { - parents-school committee members }\end{array}$ & $\begin{array}{l}\text { - non-physical non-verbal direct } \\
\text { - non-physical non-verbal indirect }\end{array}$ \\
\hline
\end{tabular}

Table 8 illustrates negative correlations between the concerns of school leaders and academic staffs and the intensity of all bullying types in schools (physical, non-physical verbal, non-physical non-verbal direct, non-physical non-verbal indirect bullying). Furthermore, the concerns of parents-school committee members and students have negative correlations with 3 types of bullying. Thus, the concerns of school leaders and academic staffs play a central role in controlling bullying behaviors in schools.

\section{DISCUSSION}

Bullying is not only experienced by female students but also experienced by male students. Bullying behavior that occurs in schools, regardless of its types, should receive serious attention. Shoving, teasing, pinching, clawing, hitting, kicking, cheating, property destroying, hair-shirt pulling, and glaring are bullying behaviors that often 
experienced by both male and female students in schools. Antiri (2016) also found out that in Ghana senior high school there were physical, social, verbal, cyber, and psychological bullying. Nevertheless, other types of bullying behaviors should still be the schools' attention. With regard to these conditions, any types of bullying behaviors and the victims of bullying must be handled comprehensively.

Smith (2016) stated that individual, family, school class, school and broader country factors can influence the chances of student involvement in bullying. Regarding the bullying process, bullying that occurs in the schools are mostly done by students individually. However, some actions are done by organized or unorganized groups of students. Based on the study, bullying usually takes place during class and after class, or before class. Places of bullying are in the classroom, in the school yard, and in the school canteen. This case shares similarity with what happened in Yogyakarta high schools that the locations used as a place for bullying include classrooms, empty spaces, and roads around the school (Octavianto, 2017). These findings can be a consideration for schools in understanding bullying actions done by students in schools. Organized group of bullies should receive more concerns than less organized one. Bullying setting mentioned above may give considerations for school efforts in preventing and reducing the occurrence of bullying.

Besides, it is found that students, teachers, school leaders, academic staffs, and parentsschool committee members have different level of concerns about bullying in schools. Some of them concern but some others do not. Meanwhile, to be able to prevent and reduce the occurrence of bullying in schools, special attention from all school stakeholders is needed. The findings imply that there should be shared understanding among the school stakeholders on bullying behaviors in schools in order that they give more concern for bullying or even for its victims. Moreover, Al-Raqqad, et al. (2017) suggested that teachers and the school management have to take different measures for reducing the bullying cases. Teachers and school management have to set some programs for bullies to mitigate the school bullying.

The results of this study indicate that the correlation between school stakeholder concerns and the intensity of bullying in schools tends to be negative. It suggests that the school stakeholder concerns have an important role in reducing the intensity of bullying in schools. Were the school stakeholder concerns improve, the intensity of bullying that occurs in schools can be reduced or minimized. Thus, to prevent and reduce the occurrence of bullying in schools, concerns from teachers, principals or school leaders, academic staffs, students, even parents or school committee members are absolutely needed. This is consistent with research findings of Adegboyega, Okesina, \& Jacob (2017) in which reveal that there is a significant relationship between family and bullying behavior among secondary school students with disabilities. For the role of school stakeholders in dealing with bullying in schools can be more effective, it is necessary to develop a model of anti-bullying education in schools that can be used as a reference or guide for all components of the education. There is an urgent need to develop anti-bullying policies in schools to identify and find ways of enabling students to seek out the help that they need (Jan \& Husain, 2015). 


\section{CONCLUSION}

Based on the above analysis results and findings, there are 22 bullying behaviors that tend to occur in schools. Those often experienced by students in schools are shoving, teasing, pinching, clawing, hitting, kicking, cheating, property damaging, hair-shirt pulling, and glaring.

The bullying process in schools may be done individually or by organized or unorganized groups, took place during class, after class, after school, before class, and located at the school canteen, school yard, class, outside class, and in school yard. Most bullying behaviors are done by students individually during class and after class, in the classroom, in the school yard, or in the school canteen.

The concerns of school stakeholders on the occurrence of bullying in schools vary. School stakeholders that are most concerned about the occurrence of bullying in schools are teachers (guardian teachers and guidance and counseling teachers), followed by parents-school committee members, school leaders, students, and academic staffs.

There is a negative correlation between the concerns of school leaders and academic staffs and the intensity of the four types of bullying in schools (physical bullying, nonphysical verbal, non-physical non-verbal direct, and non-physical non-verbal indirect bullying). School leaders, in this case, play an important role in providing most concerns over the occurrence of bullying behaviors in schools.

\section{REFERENCES}

Adegboyega, L. O., Okesina, F. A., \& Jacob, O. A. (2017). Family relationship and bullying behaviour among students with disabilities in Ogbomoso, Nigeria. International Journal of Instruction, 10(3), 241-256. https://doi.org/10.12973/iji.2017.10316a.

Al-Raqqad, H. K., et al. (2017). The impact of school bullying on students' academic achievement from teachers point of view. International Education Studies, 10(6), 44-50.

Amaniya. (2019). 5 Alasan Pentingnya Pendidikan Moral Bagi Generasi Zaman Now. https://www.idntimes.com/life/inspiration/amaniya/pentingnya-pendidikan-moral-bagigenerasi-zaman-now-c1c2/full. Cited on October 7, 2019.

Antiri, K. O. (2016). Types of bullying in the senior high schools in Ghana. Journal of Education and Practice, 7(36), 131-138

Asikin, Z. (2009). Bullying di Sekolah Kita. https://ompundaru.wordpress.com/2009/ 02/17/bullying-di-sekolah-kita.

Assegaf, A. R. (2013). Pendidikan tempat kekuatan, tipologi, kasus, dan konsep. Yogyakarta: Tidia Wacana

Astuti, P. R. (2008). Meredam bullying: 3 cara efektif menanggulangi kekerasan pada anak. Jakarta: Grasindo. 
Elliot, M. (2002). Bullying: A practical guide to coping for school. London: Pearson Education Ltd.

Hidayati, N. (2012). Bullying pada anak: Analisis dan alternatif solusi. INSAN 14(1), 41-48. http://journal.unair.ac.id/filerPDF/artikel\%205-14-1.pdf.

Jan, A., \& Husain, S. (2015). Bullying in elementary schools: Its causes and effects on students. Journal of Education and Practice, 6(19), 46-57.

Koesoema A., D (2007). Pendidikan Karakter: Strategi Mendidik Anak di Zaman Global. Jakarta: Grasindo.

Lembaga Penelitian. (2010). Pedoman penelitian. Yogyakarta: Lembaga Penelitian Universitas Negeri Yogyakarta.

Lickona, T. (1991). Educating for character: how our school can teach respect and responsibility. New York: Bantam Books.

Michael, H. (2017). Bullying. https://www.kompasiana.com/hansmichael/ 59f87b5c8dc3fa682c20c892/bullying?page=all. Cited on October 7, 2019.

Octavianto, M. R. (2017). Perilaku Bullying di Sekolah Menengah Atas Kota Yogyakarta. Jurnal Riset Mahasiswa Bimbingan dan Konseling, 3(8), 376-385.

Salmi, S, Hariko, R, \& Afdal, A. (2018). Hubungan kontrol diri dengan perilaku bullying Siswa. Counsellia: Jurnal Bimbingan dan Konseling, 8(2) 88-99. Available online at: http://e-journal.unipma.ac.id/index.php/JBK DOI: 10.25273/counsellia.v8i2.2693.

Smith, P. K. (2016). Bullying: Definition, types, causes, consequences and intervention. Social and Personality Psychology Compass, 10(9), 519-532.

The Asian Parent Indonesia. (2010). Bullying di Sekolah. https://id.theasianparent.com/si-penindas-di-kelas. Cited on October 7, 2019.

Thompson, D., Arora, T., \& Sharp, S. (2002). Bullying: Effective strategic for long term improvement. London: Routledge \& Farmer.

Ulfah, S. R. (2015). Penanganan Kasus Bullying di Sekolah. https://www. kompasiana.com/syafitrirahmaniaulfah/54f91eb6a3331t135028b4803/penanganankasus-bullying-di-sekolah. 